Ayurlog: National Journal of Research in Ayurved Science

\title{
Sutika Paricharya and its importance
}

\section{Sukeshini L. Patingrao*1, Salim S. Mulla ${ }^{2}$}

${ }^{1}$ Post Graduate Scholar,

${ }^{2}$ Professor, Guide \& HOD,

Department of Prasuti Tantra Avum Striroga, SMBT College and Hospital, Nandi Hills,

Dhamangaon, Igatpuri, Nashik, Maharashtra, India.

*Corresponding author: Email : sukeshnipatingrao@gmail.com

\section{ABSTRACT}

A woman is always given importance in Ayurveda by elucidating care at every phase of her life in respect of Rajaswala paricharya (menstrual care), Garbhini Paricharya ( Ante Natal Care), and Sutike Paricharya (Post natal Care). L Ayurveda,the term Sutika (Puerperal women) can be used only after expulsion of placenta. ${ }^{[1]}$ Puerperium is the period following child birth during which the body tissues especially the pelvic organs revert back to pre pregnant state; both anatomically and physiologically. ${ }^{[2]}$ Due to development of foetus,instability of body tissues, exertion of labour pains and excretion of moisture and blood, woman becomes very weak. After following proper purperial care, woman regains all the lost energy and reaches to pre-pregnant status. ${ }^{[3]}$

AIMS :

To review the literature of Sutika, Sutika Kaala, Sutika samanya and vishishta Paricharya, pathya and apathya with importance of Sutika paricharya.

\section{MATERIAL AND METHODS :}

It is a conceptual study and data on sutika paricharya is collected from various samhitas. Clinical importance of Sutika paricharya is also reviewed. Basic principle of sukita paricharya is pentioned.After explaining Sutika, Sutika kaala, sutika samanya and vishishtha paricharya \& its pathya and apathya is elaborated according to different samhitas

\section{RESULTS :}

Sutika who becomes weak due to development of foetus, loss of Dhatus, excretion of Kleda, blood and exhaustion due to labour pains regains her prepregnant state by following this Paricharya.

\section{CONCLUSION :}

Thousands of years ago, Ayurveda described diets and regimens in Sutika Kaala is totally scientific. After following Sutika Paricharya, Sutika can achieve Garbhashyashuddhi, Dhatu paripurnatva and Sthanya vriddhi and avoid post natal complications. 
Key Words : Sutika, Sutika Paricharya, Ayurveda, Puerperium

\section{INTRODUCTION}

A woman is always given importance in Ayurveda by elucidating care at every phase of her life in respect of Rajaswala paricharya (menstrual care), Garbhini Paricharya ( Ante Natal Care), and Sutika Paricharya (Post natal Care). In Ayurveda,the term Sutika (Puerperal women) can be used only after expulsion of placenta. ${ }^{[1]}$ As per modern medical science the puerperium is the period following child birth during which the body tissues especially the pelvic organs revert back to pre-pregnant state ;both anatomically and physiologically. ${ }^{[2]}$ Post natal care is a period following child birth which can be co-related with Sutik Paricharya as given in Ayurveda. In thi period, recovery of the women after delivery and educate her for proper care of baby is done.

Due to development of foetus,instability of body tissues, exertion of labour pains and excretion of moisture and blood, woman becomes very weak. After following proper purperial care, woman regains all the lost energy and reaches to pre-pregnant status. ${ }^{[3]}$ Mithyaachar ( inappropriate physical and mental behavior) in this period definitely results in incurable diseases or diseases which are difficult to cure. ${ }^{[4]}$ It is said in ayurveda about 74 types of diseases can occur in this period if not properly managed. ${ }^{[5]}$ So ayurveda has advised a specific diet and life style regimen called Sutika Paricharya to prevent further complications and restore the health of mother.

\section{AIMS AND OBJECTIVES:}

To review the literature of Sutika, Sutika Kaala, Sutika samanya and vishishta Paricharya, pathya and apathya with clinical importance of Sutika paricharya.

\section{MATERIAL AND METHODS:}

It is a conceptual study. Data on Sutika Paricharya is gathered from classical books and organised in a systematic manner.

When it comes to the postpartum care, Ayurveda suggests women should be treated with warmth, wetness and unctuousness as part of their therapy. This purpose can be achieved by rectifying food preparations according to the imbalance of Dosha, keeping the home warmer, providing appropriate rest and by administering daily peaceful massage with warm oil. Food preparations advised are aimed at supporting digestion, restoration and lactation. After childbirth a woman's digestive agni is weakened and needs to be rekindled and nurtured. Ayurveda focuses on foods that are warm, wet, oily, and have sweet, sour and salty tastes, to bring equilibrium of Vata.

- $\quad$ Sutika : A woman who has just given birth to a child followed by expulsion of the placenta is known as Sutika. ${ }^{[1]}$

Puerperium is the period following child birth during which the body tissues especially the pelvic organs revert back to 
pre pregnant state;both anatomically and physiologically. ${ }^{[2]}$

\section{- SUTIKA KAALA (Duration of post natal phase):}

According to different Acharyas

\begin{tabular}{|c|c|}
\hline $\begin{array}{l}\text { Ayuvedic } \\
\text { Classical Text }\end{array}$ & Sutika Kaala \\
\hline $\begin{array}{l}\text { Sushrutha } \\
\text { Samhita }\end{array}$ & $\begin{array}{l}1^{1 / 2} \text { month or until } \\
\text { next rajodarshan }\end{array}$ \\
\hline $\begin{array}{l}\text { Kashyapa } \\
\text { Samhita }\end{array}$ & 6 months $^{[7]}$ \\
\hline Ashtanga Hridaya & $\begin{array}{l}1^{1 / 2} \text { month or until } \\
\text { next rajodarshan }\end{array}$ \\
\hline Yogaratnakara & 1 month $^{[9]}$ \\
\hline Bhavprakasha & $\begin{array}{l}\text { Same as Sushrutha } \\
\text { Samhita i.e. } 1^{1 / 2} \\
\text { month and also added } \\
\text { that following } \\
\text { subsidence of } \\
\text { complication and } \\
\text { aggravation of } \\
\text { Doshas, woman } \\
\text { should give up } \\
\text { specific mode of life } \\
\text { following } 4 \\
\text { months. }\end{array}$ \\
\hline
\end{tabular}

There are different opinions about Sutika kaala,ranging from 6 weeks to 6 months and some also believe it lasts until next rajodarshan.

Puerperium begins as soon as the placenta is expelled and lasts for approximately 6 weeks. The period is divided into: ${ }^{[1]}$

1. Immediate - within 24 hours

2. Early - Upto 7 days

3. Remote - upto 6 weeks

\section{- SUTIKA PARICHARYA:}

A care of the woman during puerperium comes under the heading of
Sutika Paricharya. Its principles are given as follows:

1)Vatashamana

2 )Agnideepana

3) Pachana

4) Raktavardhaka

5) Stanyavardhaka

6) Yonisanrakshaka

7) Garbhashayashodhaka,

8) Kostashodaka

9) Dhatupusti, Balya

\section{* Samanya Paricharya}

1) Manidhaaran for Puerperal Women :

The Sutika should fix amulet of trivruta ( perculina turpethum ) over her head. It is ort of psychological support to her. Thus may protect her from harmful things. ${ }^{[12]}$

\section{2) Bath for sutika (Prasuta Snana):}

According to the rituals of family the bathing ceremony of puerperal women should be performed on $10^{\text {th }}$ or $12^{\text {th }}$ day after delivery. ${ }^{[13]}$

\section{3) Paricharya}

According to Charak Samhita ${ }^{[14]}$ :

\begin{tabular}{|c|c|}
\hline Aahara & Vihara \\
\hline $\begin{array}{l}\text { Snehapana and } \\
\text { yavagupana which } \\
\text { is medicated with } \\
\text { pippali (piper } \\
\text { longum), } \\
\text { pippalimoola (piper } \\
\text { longum's root), } \\
\text { chavya (piper } \\
\text { retrofractum), } \\
\text { chitraka (plumbago }\end{array}$ & $\begin{array}{l}\text { Abhyanga of } \\
\text { abdomen with taila } \\
\text { or ghrita. } \\
\text { Udarveshtana } \\
\text { with a big clean } \\
\text { cloth. } \\
\text { Parisheka } \\
\text { (Irrigation) with } \\
\text { luke warm water. }\end{array}$ \\
\hline
\end{tabular}




\begin{tabular}{|l|l|}
\hline zeylanica), shunthi & \\
(zinziber officinale) & \\
for 5-7 days after & \\
delivery. Anupana - & \\
Ushna Jala. & \\
Use of Brihagana & \\
drugs from $6^{\text {th }}$ or $8^{\text {th }}$ & \\
day. & \\
\hline
\end{tabular}

According to Sushrutha Samhita ${ }^{[15]}$ :

\begin{tabular}{|c|c|}
\hline Aahara & Vihara \\
\hline 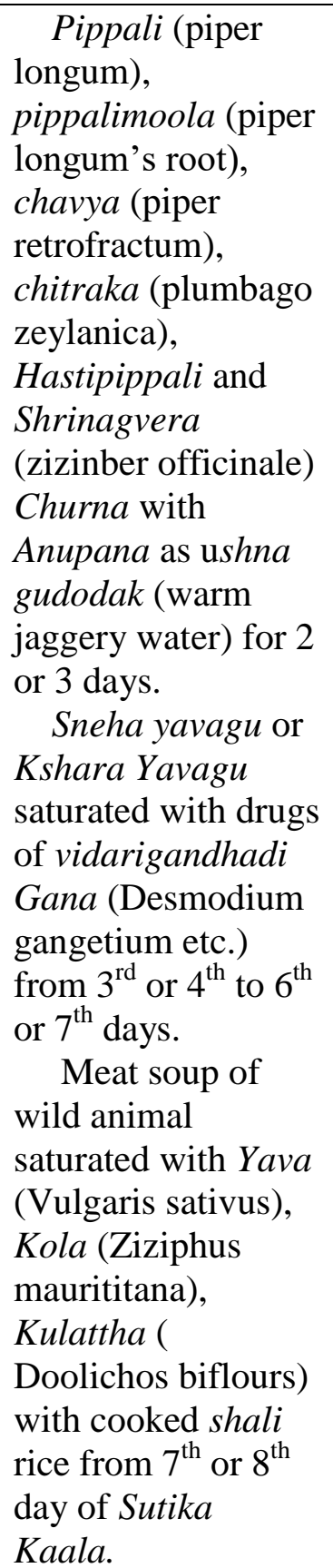 & $\begin{array}{l}\text { Abhyanga with } \\
\text { Bala taila (Sida } \\
\text { cordifolia). } \\
\quad \text { Parishek } \\
\text { (Irrigation) with } \\
\text { decoction of } \\
\text { Bhadradaru } \\
\text { (Cedrus deodara) } \\
\text { etc. Drugs capable } \\
\text { of suppressing the } \\
\text { Vata. }\end{array}$ \\
\hline
\end{tabular}

According to Ashthangasangraha Samhita [16].

\begin{tabular}{|l|l|}
\hline \multicolumn{1}{|c|}{ Aahara } & \multicolumn{1}{|c|}{ Vihara } \\
\hline \multicolumn{1}{|c|}{ Liquid Yavagu } & \multicolumn{1}{c|}{ Abhyanga with } \\
prepared with & bala taila(Sida \\
either milk or & cordifolia). \\
Vidaryadi Gana & Udarveshtana \\
(pueraria tuberose & After massage of \\
etc.) drugs for 3,5 & abdomen with Taila \\
or 7 days. Light & or Ghrita. \\
diet with soup of & Parisheka with \\
yava (Vulgaris & luke warm water. \\
sativus), Kola & Massage unguent \\
(Ziziphus & irrigation and \\
maurititana), & bathing with \\
Kulattha ( & jivaniya and \\
Doolichos biflours) & brimhaniya,madhura \\
from 4 ${ }^{\text {th }}$,6th or $8^{\text {th }}$ & and vatahara drugs. \\
\hline
\end{tabular}

Meat soup of

wild

animals, agreeable

diet from $13^{\text {th }}$ to
According to Ashtangahridaya Samhita ${ }^{[17]}$.

\begin{tabular}{|l|l|}
\hline Aahara & Vihara \\
\hline \multicolumn{1}{|c|}{ Taila or Ghrita } & Abhyanga with \\
with Panchakola & bala taila (Sida \\
(piper longum, piper & cordifolia). \\
longum's root, piper & Udarveshtana \\
retrofractum, & After massage of \\
plumbago zeylanica, & abdomen with Taila \\
zinziber officinale) & or Ghrita. \\
churna with Anupana & Parisheka with \\
as Ushna gudodaka & luke warm water. \\
(warm jaggery water) & Massage unguent \\
for 2 or 3 days. & irrigation and bathing \\
Panchakola Siddha & of body along with \\
Peya for First 3 days. & Yoni with jivaniya \\
Vidaryadi Gana & and brimhaniya, \\
Kwatha Siddha & madhura and \\
Snehayukta Yavagu or & vatahara drugs. \\
Kshira Yavagu from & \\
$4^{\text {th }}-7^{\text {th }}$ day, after that & \\
gradually brimhana & \\
diet from $8^{\text {th }}$ - 12 & \\
day, meat soup should & \\
be used. & \\
\hline
\end{tabular}


According to Kashyapa Samhita ${ }^{[18]}$ :

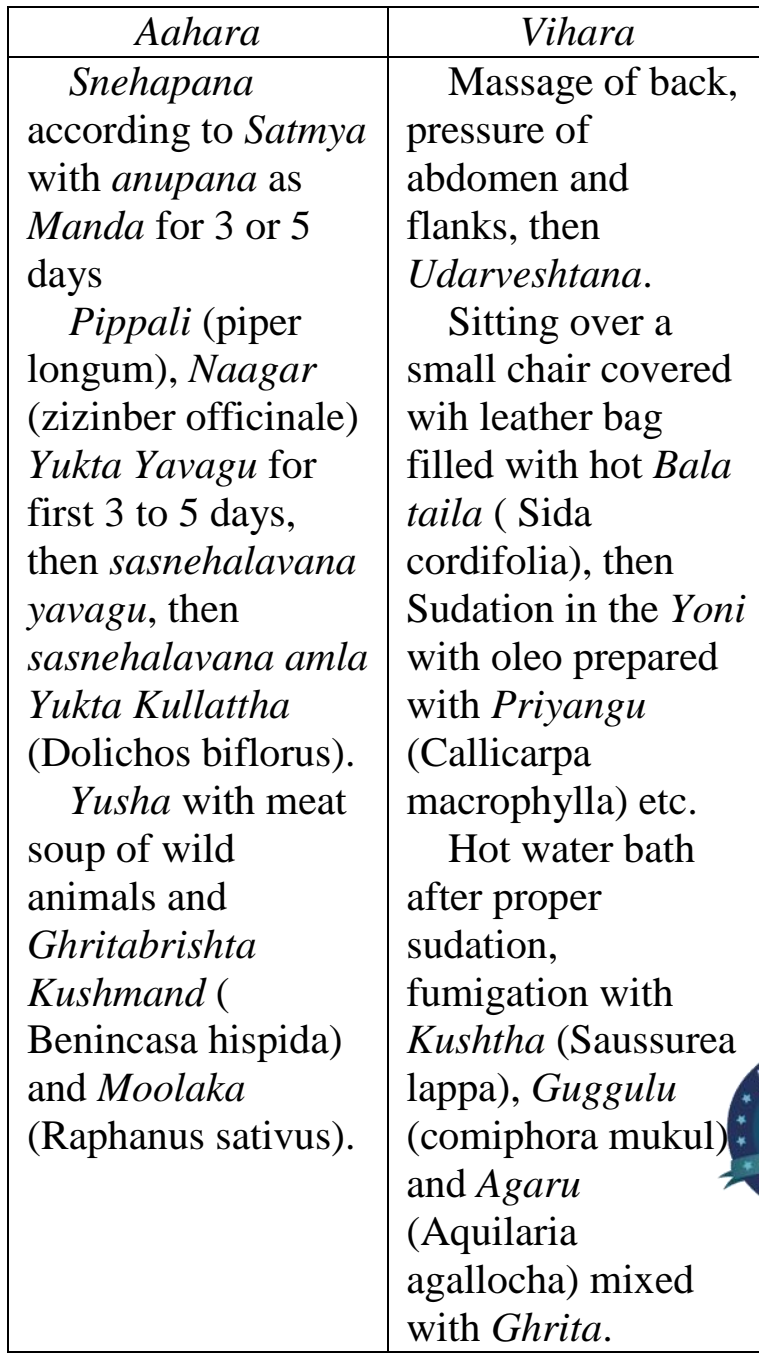

According to Harita Samhita ${ }^{[19]}$ :

\begin{tabular}{|l|l|}
\hline \multicolumn{1}{|c|}{ Aahara } & \multicolumn{1}{c|}{ Vihara } \\
\hline \multicolumn{1}{|c|}{ Ushna Kulattha } & \multicolumn{1}{c|}{ Vaginal filling with } \\
(Dolichos biflorus) & oil and massage \\
Yusha on $2^{\text {nd }}$ day, & following by sudation \\
Panchakola, Yavagu & with hot water. \\
on $3^{\text {rd }}$ day, & \\
Chaturjataka & \\
(cinnamomum $^{\text {zeylanicum, Elettaria }}$ & \\
cardmomum, leaves & \\
of cinnamomum & \\
zeylanicum, mesua & \\
ferrea) mixed yavagu & \\
on $4^{\text {th }}$ day,cooked rice \\
of shali or shastika on \\
$5^{\text {th } \text { day. }}$ \\
\hline \multirow{2}{*}{ VISHISTHA PARICHARYA: ${ }^{[20]}$} \\
\hline
\end{tabular}

It is given on the basis of Desha and sex of child

According to Desha:

\begin{tabular}{|c|c|c|c|}
\hline \multicolumn{2}{|c|}{ Desha } & Aahara & Vihara \\
\hline \multicolumn{2}{|c|}{$\begin{array}{l}\text { AnupaDesh } \\
\text { a }\end{array}$} & $\begin{array}{l}\text { 1) } \\
\text { Mandaprayog } \\
\text { a with agni- } \\
\text { balavardhaka } \\
\text { dravya } \\
\text { 2) } \\
\text { Ushnadravyas } \\
\text { evana }\end{array}$ & $\begin{array}{l}\text { Swedana } \\
\text { NivataSha } \\
\text { yana }\end{array}$ \\
\hline \multicolumn{2}{|c|}{$\begin{array}{l}\text { JangalDesh } \\
\text { a 3-5 days }\end{array}$} & Snehopachara & $\begin{array}{l}\text { Snehopach } \\
\text { ara }\end{array}$ \\
\hline \multicolumn{2}{|c|}{$\begin{array}{l}\text { Sadharana } \\
\text { Desha }\end{array}$} & $\begin{array}{l}\text { Neither too } \\
\text { snehan } \\
\text { dravyas nor } \\
\text { rukshadravyas }\end{array}$ & \\
\hline \multicolumn{2}{|c|}{ VideshaJati } & $\begin{array}{l}\text { Rakta, } \\
\text { Mamsaniryuh } \\
\text { a, } \\
\text { Kandamoola, } \\
\text { Phala }\end{array}$ & \\
\hline \multicolumn{4}{|c|}{ According to sex of child: } \\
\hline \multicolumn{4}{|c|}{\begin{tabular}{l|r} 
Sex & Pathya
\end{tabular}} \\
\hline Male & \multicolumn{3}{|c|}{$\begin{array}{l}\text { Tailapana } \\
\text { Deepaniyaaushadhisamsakritayav } \\
\text { agupana }\end{array}$} \\
\hline $\begin{array}{l}\text { Fema } \\
\text { le }\end{array}$ & \multicolumn{3}{|c|}{$\begin{array}{l}\text { Ghritapana } \\
\text { Deepaniyaaushadhisamsakritayav } \\
\text { agupana }\end{array}$} \\
\hline
\end{tabular}

Pathya And Apathya: ${ }^{[21]}$

Pathya:

1) Sutika should have bath with warm water.

2) Sutika should have boiled water for drinking. 
3) Sutika should have adequuate sleep.

4) Sutika should do udarveshthana regularly.

5) Sutika should have hitakaraka ahara and vihara.

6) Luke warm oils should be used for Abhyanga and luke warm water should be used for Parisheka, Avagahana

7) Everyday snehana and swedana must be done.

Apathya :

1) Cold water, cold wind and cold things.

2) Sexual intercourse

3) Physical and mental Stress.

4) Contra-indication of Panchakarma for Sutika

A) Due to Nasya Karma,emaciation anorexia, body ache would occur in sutika

B) Due to administration of Asthapana basti, amadosha of sutika would be increased.

5) Excessive exercise.

6) Anger, Fear and Depression.

7) Atapasevana and divaswapa.

\section{Importance of sutika paricharya :}

1) Snehana is vatashamaka.

2) Uttama Stanya is produced by Uttama Rasa which depends on the quality of agni.

3) There is agnimandya in Sutika so agni deepana is the basic need of treatment for few days immediately after delivery, which is done before giving brimahana drugs.Agnivardhaka drugs are first given to Sutika After delivery.

4) Use of mamsa rasa and brimhaniya dravyas like jeeviniya, brimhaniya or madhura dravyas acts as dhatuvardhaka and it helps to maintain proper lactation.

5) Yava, Kola laghu annapana is advised for 5 days as this helps to replenish Dhatu.

6) Bala taila is advised in nyubja position for Abhyanga which might help in suppressing vata.

7) Kwatha prepared by vatahara dravyas for parishechana act as Vedanahara and kledahara.

8) Dhupana as rakshaghna and vedanahara is mentioned and kushtha, uggulu and agaru is used.

9) To prevent problems during Sutika kaala such as as UTI,Thirst,Anxiety, backache, anger, disturbed sleep, depression, etc.

10) Udarpattabandhana- wrapping abdomen with long and clean cloth which helps abdomen to retrieve its normal position and then there is no accumulation of vata in vacant place.

\section{Discussion :}

1) Abhyanga: Abhyanga given to Sutika may be Sthanika(udara or yoni) or arvadaihika with the help of Ghrita and Taila especially with BalaTaila which is atasanshamaka, Rasayana to Mamsadhathu; Shramahara. Abhyanga tones up the pelvic floor, abdominal, back muscle, tissues and relieve the muscle spasm. It also elps in recovery 
from soft tissue injury by increased circulation. Improves the igestion, increases red blood cells \& prevents anaemia. It prevents thrombosis by ubbing \& friction improves the venous blood flow by dilating superficial blood vessels.

Abhyanga at lower back helps for proper drainage of lochia. Yoni Abhyanga tones up vagina and perineum and prevents laxity and prolapse, alleviates pain and heals aginal and perineal wounds.

2) Parisheka \& Avagaha: Parisheka is pouring hot water in a stream, it is atakaphahara, vedanahara, does agnideepti, twakaprasannata, srotoniramalata, so hat abnormal blood clots accumulated in uterine cavity after the delivery of Garbha xcreted properly and VataDosha also subsides.

\section{3) Udaraveshtana (Pattabandana):}

prevents vitiation of vatadosha compressing hollow space produced after expulsion of foetus. Abdomen should be tightly wrapped ith long cotton cloth after bath. It provides support to the back $\&$ abdomen. It mainly elps the uterus to shrink back to its normal size. Also helps to straighten back after pregnancy, improving posture

4) Yonidhupana: Vaginal defence is lowered due to hypoestrogenic state and patient is prone for infection. Dhupana will maintain the hygiene of the perineum. It keeps pisiotomy healthy, hastens its healing process. The drugs used like kusta, agaru, ggulu have the properties like jantugna, kandugna, shothahara, vranashodhana, ropana. In Yonipindana vagina is advised to cover completely.
This restricts entry of Vata and prevents vagina from various infections.

\section{RESULTS:}

Sutika who becomes weak due to development of foetus, loss of Dhatus, excretion of Kleda, blood and exhaustion due to labour pains regains her prepregnant state by following this Paricharya. And we can summarize post natal care in Ayurveda as follows:

1. It strengthen and improves digestion

2. It increase emotonal steadiness psychlogical alertness and apparent thinking.

3. It tones muscles, calms nerves and greases all joints.

It helps woman's body to get back into her normal shape.

5. Effortless lactation and more restful feeding.

\section{CONCLUSION:}

Thousands of years ago, Ayurveda described diets and regimens in Sutika Kaala is totally scientific. After following Sutika Paricharya, Sutika can achieve Garbhashyashuddhi, Dhatu paripurnatva and Sthanya vriddhi and avoid post natal complications. After a thorough review of various classical texts, it can be easily concluded that Ayurveda has executed Sutika Paricharya in a meticulous fashion focusing on every aspect required to nurture and replenish the health of woman and avoid post-partum complications. 


\section{REFERENCES:}

1. Kashyapa Samhita (Vridhajeevakeeya Tantra) Sharma H, editor $4^{\text {th }}$ edition, Chaukhambha Sanskrit Samsthana, Varanasi 1988;p.305

2. D.C. Dutta's Textbook of Obstetrics, edited by Hiralal Konar, $6^{\text {th }}$ edition; New Central Book agency (P) Ltd, Kolkatta, 2004;p.145

3. Astanga Sangraha Vol 1. Gupta Atridev, editor $1^{\text {st }}$ ed. Varanasi; Oriental publishers, 1993;p.288

4. Sushruta Samhita, Jadhavji Trikamji, editor. $5^{\text {th }}$ ed. Chaukhambha Orientalia, Varanasi, 1992;p.389

5. Prof,(km)P.V.Tiwari, Ayurvediya prasutitantra \& Streeroga, Prasutitantra, First part, Chaukhambha Sanskrit Samsthan, Varanasi, 2003;p.559

6. Ambikadutta shastri (editor). Sushrutha Samhita, sharira sthana, chap-10, Bharati Chaukhambha Subharti Prakashana, Varanasi 2010;p.103

7. Satyapala bhigacharya (editor), Kashyapa Samhita (Vriddha Jeevaka), Khilasthana, chap-11, $4^{\text {th }}$ ed. Chaukhambha Sanskrit Sansthan, Varanasi. 1994;p.305

8. Premvati Tiwari, Ayurvediya Prasuti Tantra evam Striroga,part 2, chap-9, $2^{\text {nd }}$ ed., Chaukhambha Orientalia, Varanasi. 1996;p.569

9. Sartha Yogaratnakar, Datto Ballala Borkar, translator, vol $2^{\text {nd }}$, Sutika Chikitsa, chap-44, Shri Gajanana Book Depo Prakashana, Pune, 1984;p.639
10. Purushottam nanal, editor, Sartha Bhavaprakasha,Purva Khanda, chap-3, $1^{\text {st }}$ ed. Shri Gajanana Book Depo, Pune. 1929;p.42

11. D.C. Dutta's Textbook of obstetrics, edited by Hiralal Konar, $7^{\text {th }}$ edition, pubJaypee brothers medical publishers (P) Ltd, New Delhi, 2013,p.144

12. Kashyapa Samhita Of Vriddha Jeevaka,Satyapala Bhigacharya, Varanasi, pub-Chaukhambha Sanskrit Sansthan, edi1994, Khilasthana chapter 10, 4th edition;p.181

13. Asthanga Sangraha Of Vagbhata, byKashinath Shastri, pub-Chaukhambha Orientalia, 9th edition, 2005; p.376.

14. Charaka Samhita, of Agnivesha, revised by Charaka Acharya ,Yadavaji Trikamaji Chaukhambha Orientalia,5th dition, 2001;p.348

15. Sushruta Samhita Of Sushruta, byAcharya Yadavaji Trikamaji, pubChaukhambha Orientalia,8th edition ,2005; p.389.

16. Asthanga Sangraha Of Vagbhata, byKashinath Shastri, pub-Chaukhambha Orientalia,9th edition, 2005;p.376.

17. Prof,(km)P.V.Tiwari, Ayurvediya Prasutitantra \& Streeroga, Prasutitantra First-Part, pub-Chaukhambha Sanskrit Samsthan,2003;p.549.

18. Kashyapa Samhita by Pt. Hemaraj Sharma, pub-Chaukhambha Sanskrit Sansthan, 10th edition,2005;p.306.

19. Harita Samhita with Nirmala Hindi Commentary by Acharya Ramavalamba Shastri,1st edition , Prachya prakashana, Varanasi, 1985;p.104 
20. Shrisatyapal Bhishagacharya, Kashyapa Samhita with Vidyothini Hindi Commentary. Khilasthana $11 / 32-33,8^{\text {th }}$ edition, Chaukhambha Sanskrit Samsthan, Varanasi, 1988;p.307
21. Srivastava Sarika et. Al.,"Role of Shigru in Management of Sutika-Arti (pierperal - discomfort)" Department od Prasuti Tantra, IMS, BHU, Varanasi, 2000;p.17-18

\section{Cite article:}

